\title{
Staphylococcus: Isolation, Identification and Antimicrobial Resistance in Dairy Cattle Farms, Municipal Abattoir and Personnel in and Around Asella, Ethiopia
}

\section{Fufa Abunna ${ }^{1 *}$, Tekeste Abriham ${ }^{1}$, Fikru Gizaw ${ }^{2}$, Takele Beyene ${ }^{1}$, Ashenafi Feyisa ${ }^{1}$, Dinka Ayana ${ }^{1}$, Bedaso Mamo $^{1}$ and Reta Duguma ${ }^{1}$}

${ }^{1}$ College of Veterinary Medicine and Agriculture, Addis Ababa University, PO Box 34, Bishoftu, Oromia, Ethiopia

${ }^{2}$ College of Veterinary Medicine, Semera University, PO Box 132, Samara, Ethiopia

\begin{abstract}
A cross sectional study was conducted between February, 2014 and April, 2014 to isolate and identify Staphylococcus from dairy cattle farms and municipal abattoir; and to evaluate antimicrobial sensitivity for isolates in and around Asella, Ethiopia. An over all of 181 samples were collected and processed from nine dairy cattle farms (87) and seven municipal abattoir visits (94). Accordingly, 42 (23.2\%) udder milk, $9(5.0 \%)$ tank milk, 9 (5.0\%) polled bucket swab, $9(5.0 \%)$ tank swab, $9(5.0 \%)$ polled hand swab, $9(5.0 \%)$ polled nasal swab, from dairy cattle farms; and $66(36.5 \%)$ meat swab, 7 (3.9\%) polled knife swab, 7 (3.9\%) polled slaughter line swab, 7 (3.9\%) polled hand swab and $7(3.9 \%)$ polled nasal swab from municipal abattoir visits were collected. The result showed the overall proportion of Staphylococcus was $89(49.2 \%)$. Staphylococcal species were more predominant in abattoir 50/94 $(53.2 \%)$ than farms $39 / 87(44.8 \%)$, but there was no significant difference between them because $p>0.05$ at $95 \%$ confidence interval. Also high proportion of Staphylococcus was isolated from polled farm nasal swab 8/9 (88.9\%), but this difference between sample type and the presence of Staphylococcus is not significant, because p-value $(0.303)$ is greater than 0.05 at 0.05 level. Up on isolation and identification $35(19.3 \%), 6(3.3 \%), 24(13.3 \%), 24$ $(13.3 \%)$ were S. aureus, S. intermedius, S. hyicus and Coagulase Negative Staphylococci (CNS), respectively. From total positive samples, 55 isolates were tested for antimicrobial susceptibility to different 15 antimicrobial discs. The comparative efficacies of antimicrobials used indicates Gentamycin, Kanamycin, Chloramphenicol, Ciprofloxacillin, and Sulphamethoxazole trimethoprim, were the most effective antibiotics where by $94.5 \%, 89.1 \%, 81.8 \%, 81.8 \%$, and $81.8 \%$ respectively. Good hygienic practices should be followed both in dairy cattle farms and municipal abattoir including working personnel and equipment's used; and antimicrobials susceptibility test should be carried out at regular intervals to find out the development of resistance against the most commonly applied antibiotics.
\end{abstract}

Keywords: Abattoir; Antimicrobial susceptibility; Asella; Farm; Identification; Isolation; Staphylococcus

\section{Introduction}

Globally, millions of people suffer from communicable and noncommunicable diseases caused by contaminated foods $[1,2]$. There are three ways people are exposed to Food Borne Diseases (FBD) due to pathogenic bacteria in foods of animal origin meat (beef, mutton, pork), dairy (milk, cheese, yoghurt, ice cream) and eggs [3,4]. Food borne diseases are universal public health problems and the implications are great including health and economic losses $[5,6]$.

Food borne diseases or food poisonings are defined by the World Health Organization (WHO) as an illness or diseases of infectious or toxic nature caused by the consumption of foods or water contaminated with bacteria and/or their toxins, parasites, viruses, or chemicals $[7,8]$. Food borne diseases are major health problems in developed and developing countries. The World Health Organization (WHO) estimated that in developed countries, up to $30 \%$ of the population suffers from food borne diseases each year, whereas in developing countries up to 2 million deaths are estimated per year [9]. Many diseases are communicable and caused by micro-organisms that enter into the body via food [10]. Numerous outbreaks of gastroenteritis have been associated with ingestion of raw foods, foods incorporating raw ingredients or foods obtained from unsafe sources [11,12].

In the last few decades, staphylococcal food poisoning has been reported as third cause of food-borne illnesses in the world. Among the foods implicated in staphylococcal food poisoning, milk, dairy products and meats, particularly handled foods, play a vital role since entero-toxigenic strains of $S$. aureus have been commonly isolated in them [13]. S. aureus is present in a variety of locations on the dairy farms, and several studies suggested that transfer of $S$. aureus between humans and cows is possible [14]. Multidrug-resistant staphylococcal isolates such as Methicillin-Resistant S. aureus (MRSA) were isolated primarily from human samples, but such isolates were detected in animal samples $[15,16]$. Thus, the transfer of $S$. aureus between humans and cows may result in serious problems.

Milk, dairy products and meat, especially handled foods, are common vehicles that are frequently implicated in Staphylococcal Food Poisoning (SFP) [17,18]. Milk can be contaminated for example by Staphylococcus aureus when there is infection of the mammary gland or by bad hygiene habits, such as coughing or sneezing and not washing hands when handling milk storage equipment, during or after milking, and in this case, human activity is responsible for the contamination, as these bacteria colonizes the nasal pathways in human beings [19]. With regards to meat, it is a good material for bacterial growth; its quality

*Corresponding author: Fufa Abunna, College of Veterinary Medicine and Agriculture, Addis Ababa University, PO Box 34, Bishoftu, Oromia, Ethiopia, Tel +251911899435; E-mail: fufa.abunna@aau.edu.et

Received August 02, 2016; Accepted September 06, 2016; Published September 13,2016

Citation: Abunna F, Abriham T, Gizaw F, Beyene T, Feyisa A, et al. (2016) Staphylococcus: Isolation, Identification and Antimicrobial Resistance in Dairy Cattle Farms, Municipal Abattoir and Personnel in and Around Asella, Ethiopia. J Vet Sci Technol 7: 383. doi: 10.4172/2157-7579.1000383

Copyright: $\odot 2016$ Abunna F, et al. This is an open-access article distributed under the terms of the Creative Commons Attribution License, which permits unrestricted use, distribution, and reproduction in any medium, provided the original author and source are credited. 
Citation: Abunna F, Abriham T, Gizaw F, Beyene T, Feyisa A, et al. (2016) Staphylococcus: Isolation, Identification and Antimicrobial Resistance in Dairy Cattle Farms, Municipal Abattoir and Personnel in and Around Asella, Ethiopia. J Vet Sci Technol 7: 383. doi: 10.4172/21577579.1000383

Page 2 of 7

depends on the initial bacterial contamination. This contamination causes meat deterioration, lowers quality and sometimes illness may be caused by bacterial pathogens or their toxins through meat and meat products [20]. External contamination of meat is a constant possibility from the moment of bleeding until consumption [21]. The possible sources of these bacteria are likely resulted from the skin of the animal from which the meat was obtained. Other potential sources of microbial contaminations are the equipment used for each operation that is performed until the final product is eaten; the clothing and hands of personnel and the physical facilities themselves are all implicated [22].

Poor personal hygiene, improper cleaning of storage and preparation areas and unclean utensils cause contamination of raw and cooked foods. Mishandling of raw and cooked foods allows bacteria to grow. Man's respiratory passages, skin and superficial wounds are common sources of $S$. aureus. When $S$. aureus is allowed to grow in foods, it can produce a toxin that causes illness. Although cooking destroys the bacteria, the toxin produced is heat stable and may not be destroyed. Many foods will support growth of staphylococci and toxin production. Good personal hygiene while handling foods will help keep $S$. aureus out of foods, and refrigeration of raw and cooked foods will prevent the growth of these bacteria if any are present [23].

In developing countries, the surveillance system of FBD hardly exists and it is therefore, difficult to estimate the real magnitude of the problem. Even in countries where surveillance services are very efficient, the precise incidence of food poisoning is not known, as outbreaks are often not reported to public health authorities. Hence, the incidence of FBD caused by staphylococci is thought to be much higher than reported since many cases remain undeclared [17,24]. Therefore, the objectives of this study were to isolate, and identify Staphylococcus species and evaluate antimicrobial susceptibility patterns in dairy cattle farms, abattoir and human in and around Asella town.

\section{Materials and Methods}

\section{Study area}

The study was conducted in Asella town dairy farms and municipal abattoir from February to April 2014. Asella town is located in Oromia region. The town, which is the capital of Arsi zone, is located at about $175 \mathrm{~km}$ Southeast of Addis Ababa at $6^{\circ} 59^{\prime}$ to $8^{\circ} 49^{\prime} \mathrm{N}$ latitudes and $38^{\circ} 41^{\prime}$ to $40^{\circ} 44^{\prime} \mathrm{E}$ longitudes with an altitude of the area ranges from 2500 to 3000 metre above sea level. Agricultural production system of the study area is of mixed crop and livestock production. Dairy farming using improved breeds is a common practice in urban and peri-urban areas. The area is characterized by mid subtropical temperature ranging from $5^{\circ} \mathrm{C}-28^{\circ} \mathrm{C}$ and with relative humidity ranging from 43 to $60 \%$. The annual average rainfall is $1200 \mathrm{~mm}$ and mostly with clay type of soil and in rare case black soil. The area has a bimodal rainfall occurring from March to April (short rainy season) and July to October (long rainy season). The area covers $23674.72 \mathrm{~km}$ square and topographically has highland escapement and lowland areas. The area is densely populated, with livestock population of 85,893 cattle, 57,118 sheep, 10,725 goats, 7841 horses, 15,642 donkeys, 517 mules and 35,489 poultry. The farmers in the area practice mixed crop-livestock farming system. The high land areas are found centrally and the low lands dominate the periphery of the area [25].

\section{Study population}

The study population were dairy cows, dairy cow milkers, slaughtered cattle's and abattoir personnel. In addition, samples were taken from materials used in milking process (farm) and slaughtering process (abattoir).

\section{Sampling method}

A total of 181 samples were collected from dairy cattle farms (87) and municipal abattoir (94). The sample size was fixed based on the representative samples taken from selected dairy cattle farms and municipal abattoir. Probability sampling (simple random) was used to select the population to be sampled. Samples were taken from nine dairy cattle farms including small scale farms and seven municipal abattoir visits. Accordingly, 42 (23.2\%) udder milk, 9 (5.0\%) tank milk, 9 (5.0\%), 9 (5.0\%) polled bucket swab tank swab, 9 (5.0\%) polled farm hand swab, 9 (5.0\%) polled nasal swab, 66 (36.5\%) meat swab, 7 (3.9\%) polled knife swab, 7 (3.9\%) polled slaughter line swab, 7 (3.9\%) polled abattoir hand swab and 7 (3.9\%) polled abattoir nasal swab was collected from representative dairy cattle farms and municipal abattoir visits in and around Asella.

\section{Study design}

A cross sectional study was carried out to isolate and identify Staphylococcus from selected dairy cattle farms and a municipal abattoir visit from February, 2014 to April, 2014. In addition, in vitro antibiotic susceptibility test was undertaken using fifteen antimicrobial discs via disc diffusion test.

\section{Study methodology}

Sample type: A total of 181 samples containing eleven sample types were collected from selected dairy cattle farms and municipal abattoir in Asella town and its surroundings. These sample types include udder milk from cows, tank milk from total collected milk in the farm, bucket swab from bucket (polled), hand (polled) and nasal swabs (polled) from milkers' hand from selected dairy farms; and meat swab from slaughtered cattle, slaughter line swab from hanging materials (polled), knife swab from knives (polled), hand (polled) and nasal swab (polled) from slaughterers from municipal abattoir was taken.

\section{Sampling procedure transportation and storage}

Meat, polled slaughter line, polled knives, polled abattoir hand and nasal swabs from municipal abattoir; and polled bucket, polled farm hand and nasal swabs from selected representative dairy cattle farms were collected using 10 milliliter of buffered peptone water containing sterile test tubes and transported inside ice containing ice box. And udder milk and tank milk was collected using sterile test tube and transported with ice containing ice box. For good collection of milk sample the teat were wiped thoroughly with $75 \%$ ethyl alcohol. The sterile collection of bottle was used and the first stream of milk from each quarter was discarded. The milk sample then held in an ice box for transportation to the laboratory. In the laboratory samples was cultured immediately or stored at $+4^{\circ} \mathrm{C}$. Swabs samples were collected using sterile cotton swabs from abattoir (meat, slaughter line, knives, hand and nasal swab), and farm (bucket, tank, hand and nasal swab). Each sterile cotton swab was dipped into sterile distilled water prior to collection.

Meat swab was taken from slaughtered carcass after flaying process was undertaken from neck and front leg, thoracic wall, abdominal wall and thigh region to make a representative sample of the carcass. This was undertaken by rotating the sterile applicator swab on those regions. Swabs from materials from abattoir (slaughter line and knives) and farm (bucket and tank) were collected by using sterile applicator swab through rotating on the body (inside) of the materials. Swab from slaughter house personnel from abattoir and milkers' hand from farm was taken by wiping both hands with sterile applicator swab. Nasal swab 
Citation: Abunna F, Abriham T, Gizaw F, Beyene T, Feyisa A, et al. (2016) Staphylococcus: Isolation, Identification and Antimicrobial Resistance in Dairy Cattle Farms, Municipal Abattoir and Personnel in and Around Asella, Ethiopia. J Vet Sci Technol 7: 383. doi: 10.4172/21577579.1000383

Page 3 of 7

for culture was obtained by firmly rotating new pre-moistened cottontipped swabs on both nares of volunteer dairy farm milkers' hand and slaughterers. After swab was taken, subsequently, it is put into a single screw capped test tube containing $10 \mathrm{ml}$ of buffered peptone water as transporting media. Then, samples for culture were placed in racks for easy handling and held in an icebox, properly packed and kept cold. Finally, it was transported to the microbiology department of Asella regional laboratory to be processed.

Antimicrobial susceptibility test was performed on selected Staphylococcus isolates according to the criteria of the Clinical and Laboratory Standards Institute [26]. For susceptibility test, one antimicrobial from each subclass of antimicrobials which were commonly used for treatment of bovines or considered as important antimicrobial agents for human were selected for antibiogram based on the criteria of Clinical and Laboratory Standards Institute [26]. Thus, antimicrobials included in this study were Erythromycin (E/15 $\mu \mathrm{g})$, Ciproflocaxin (CIP/5 $\mu \mathrm{g}$ ), Penicillin G (P/10 Units), Sulphamethoxazole trimethoprim (SXT/25 $\mu \mathrm{g}$ ), Amoxacillin (AML/25 $\mu \mathrm{g})$, Chloramphenicol $(\mathrm{C} / 30 \mu \mathrm{g})$, (Oxoid), Tetracycline (TE/30 $\mu \mathrm{g})$, Cefoxitin $(\mathrm{FOX} / 30 \mu \mathrm{g})$, Cloxacillin $(\mathrm{OB} / 5 \mu \mathrm{g})$, Kanamycin $(\mathrm{K} / 30 \mu \mathrm{g})$, Nalidixic acid $(\mathrm{NA} / 30 \mu \mathrm{g})$, Nitrofurantion $(\mathrm{F} / 50 \mu \mathrm{g})$, Streptomycin $(\mathrm{S} / 10 \mu \mathrm{g})$, Vancomycin $(\mathrm{VA} / 30 \mu \mathrm{g})$ and Gentamycin $(\mathrm{CN} / 10 \mu \mathrm{g})$ (Biomerioux). Finally, the diameters of the zone of inhibition around the disks were measured to the nearest millimeter using rulers, and the isolates were classified as susceptible, intermediate and resistant according to the interpretative standards of Clinical and Laboratory Standards Institute [26]. Moreover, isolates showing resistance to three or more antimicrobial subclass were considered as multidrug resistant.

\section{Data management and analysis}

After the data was collected using different formats, Microsoft Excel was used for data management, computation of descriptive statistics and drawing graphs. Computation of descriptive statistics was conducted using SPSS version 20.0, 2011 software. Descriptive statistics such as percentages, proportions and frequency distributions were applied to compute some of the data. The Pearson's chi-square $\left(\chi^{2}\right)$ test at a significance level of 5\% and 95\% Confidence Interval was used to determine the differences of prevalence of Staphylococcus, Staphylococcus species and Staphylococcus and staphylococcal species between samples examined, sample source and sample types. The difference was statistically significant if the $\mathrm{p}$ - value was less than 0.05 , but in significant if $\mathrm{p}$ - value is greater than 0.05 .

\section{Results}

An overall of 181 examined samples, 89 (49.2\%) were positive for Staphylococcus species, and after isolation and identification of Staphylococcus species from the total sample 35 (19.3\%), 6 (3.3\%), 24 (13.3\%), 24 (13.3\%) were S. aureus, S. intermedius, S. hyicus and coagulase negative Staphylococci (CNS), respectively. As the result shows $S$. aureus is the most prevalent staphylococcal species followed by S. hyicus and CNS; and lastly S. intermedius. From 181 samples, 94 (51.9\%) and 87 (48.1\%) were collected and examined from abattoir and farms, respectively. Staphylococcal species were more predominant in abattoir 50/94 (53.2\%) than farms 39/84 (44.8\%), but there was no significant difference between them because p-value $(0.261)>0.05$ at 95\% confidence interval (Table 1 ).

Also high proportion of Staphylococcus was isolated from polled farm nasal swab $8 / 9$ (88.9\%), consequently followed by polled knives swab 5/7 (71.4\%), polled abattoir nasal swab 4/7 (57.1\%), meat swab 35/66 (53.0\%), 3/7 (42.9\%) (for each polled slaughter line swab and polled abattoir hand swab), udder milk $19 / 42$ (45.2\%) and 3/9 (33.3\%) (for each tank milk, polled bucket swab, polled farm hand swab and tank swab). But this difference between sample type and the presence of Staphylococcus is not significant, because p-value (0.303) is greater than 0.05 at 0.05 level (Table 2).

From abattoir visits 94 samples were cultured for isolation and identification of Staphylococcus. The isolation result showed 50 (53.2\%) were positive for Staphylococcus species. Upon identification S. aureus $22(23.4 \%)$ was most predominant followed by S. hyicus $15(16.0 \%)$ CNS $11(11.7 \%)$ and S. intermedius $2(2.1 \%)$. In the abattoir visit five types of samples were examined including $66(70.2 \%)$ meat swab, 7 (7.4\%) slaughter line swab, 7 (7.4\%) polled knife swab, 7 (7.4\%) polled hand swab, and $7(7.4 \%)$ polled nasal swab. Out of these $4(57.1 \%)$, 4 (57.1\%), 35 (53.0\%), 3 (42.9\%), and 3 (42.9\%); polled nasal swab, polled knives swab, meat swab, polled hand and slaughter line swab, respectively were positive for staphylococcal species.

Out of nine farms 87 representative samples were taken and examined that $39(44.8 \%)$ were positive for staphylococcal species. From these 13 (14.9\%), 4 (4.6\%), 9 (10.3\%) and 13 (14.9) were S. aureus, S. intermedius, $S$. hyicus, and CNS, respectively.

In each farm six sample types including udder milk 42 (48.3\%), tank milk $9(10.3 \%)$, polled bucket swab $9(10.3 \%)$, tank swab $9(10.3 \%)$, polled hand swab $9(10.3 \%)$, and polled nasal swabs 9 (10.3\%) were processed. The status of Staphylococcus was high in polled nasal swab 8 (88.9\%) followed by udder milk 19 (45.2\%), tank milk 3 (33.9\%), tank swab 3 (33.9\%), polled bucket swab 3 (33.9\%) and polled hand swab 3 (33.9\%). But there is no significance difference between sample types, because $\mathrm{p}$ value 0.109 is greater than 0.05 at the 0.05 level.

A total of 32 samples, of which 16 (50.0\%) polled hand swab and 16 (50.0\%) polled nasal swab was taken and examined both from selected representative dairy cattle farms milkers' hand $14(43.75 \%)$ and municipal abattoir slaughterers 18 (56.25\%). From these 32 samples $18(56.25 \%)$ were found to be positive for Staphylococcus species, and upon identification 7 (21.9\%), 6 (18.8\%), 5 (15.6\%), and 0 (0\%) were $S$. aureus, CNS, S. hyicus and S. intermedius, respectively.

As the result shows the status of Staphylococcus species was higher in dairy cattle farm milkers' hand $11 / 18$ (61.1\%) than municipal abattoir slaughterers $7 / 14(50 \%)$. But the difference was not significant because p-value $(0.53)$ is greater than 0.05 at 0.05 levels.

\begin{tabular}{|c|c|c|c|c|c|c|c|c|c|c|}
\hline \multirow{3}{*}{ Sample source } & \multicolumn{8}{|c|}{ Staphylococcus species } & \multirow{2}{*}{\multicolumn{2}{|c|}{ Total }} \\
\hline & \multicolumn{2}{|c|}{ S. aureus } & \multicolumn{2}{|c|}{ S. intermedius } & \multicolumn{2}{|c|}{ S. hyicus } & \multicolumn{2}{|c|}{ CNS } & & \\
\hline & $\mathrm{n}$ & $\%$ & $\mathrm{n}$ & $\%$ & $\mathrm{n}$ & $\%$ & $\mathrm{n}$ & $\%$ & $\mathrm{n}$ & $\%$ \\
\hline Abattoir $(n=94)$ & 22 & 23.4 & 2 & 2.1 & 15 & 16 & 11 & 11.7 & 50 & 53.2 \\
\hline Farm $(n=87)$ & 13 & 14.9 & 4 & 4.6 & 9 & 10.3 & 13 & 14.9 & 39 & 44.8 \\
\hline Total $(\mathrm{N}=181)$ & 35 & 19.3 & 6 & 3.31 & 24 & 13.3 & 24 & 13.3 & 89 & 49.2 \\
\hline$X^{2}$ (P-value) & \multicolumn{2}{|c|}{$2.071(0.15)$} & \multicolumn{2}{|c|}{$0.860(0.35)$} & \multicolumn{2}{|c|}{$1.238(0.266)$} & \multicolumn{2}{|c|}{$1.238(0.412)$} & \multicolumn{2}{|c|}{$1.265(0.261)$} \\
\hline
\end{tabular}

Table 1: Proportion or percentage of staphylococcal isolates from municipal abattoir and dairy cattle farms in and around Asella. 
Citation: Abunna F, Abriham T, Gizaw F, Beyene T, Feyisa A, et al. (2016) Staphylococcus: Isolation, Identification and Antimicrobial Resistance in Dairy Cattle Farms, Municipal Abattoir and Personnel in and Around Asella, Ethiopia. J Vet Sci Technol 7: 383. doi: 10.4172/21577579.1000383

Page 4 of 7

From total positive samples, 55 (22 (40.0\%) S. aureus, $4(7.3 \%)$ S. intermedius, 18 (32.7\%) S. hyicus, 11 (20.0\%) CNS) was tested for susceptibility to different 15 antimicrobial discs. The comparative efficacies of antimicrobials used indicate Gentamycin, Kanamycin, Chloramphenicol, Ciprofloxacillin, and Sulphamethoxazole trimethoprim, were the most effective antibiotics where by $94.5 \%, 89.1 \%$, $81.8 \%, 81.8 \%$, and $81.8 \%$ respectively. Penicillin G (14.5\%), Nalidixic acid (25.5\%), have shown the poorest in efficacy against staphylococcal isolates. The number and percentage of susceptibility pattern of 55 staphylococcal isolates with fifteen antimicrobials are listed on Table 3.

As the result shows staphylococcal species have showed a slightly variable susceptibility pattern toward antimicrobials (Table 4). S. aureus is highly susceptible (90.9\%) to both Gentamycin and Kanamycin; and highly resistant to Penicillin G (95.5\%). S. intermedius also showed greater susceptibility (100.0\%) towards Gentamicin, Amoxicillin, Chloramphenicol, Sulphamethoxazole trimethoprim, Tetracycline, Vancomycin and Kanamycin; but is resistant to Penicillin G (75.0\%). Similarly, S. hyicus was highly susceptible to Gentamycin (94.4\%), but resistant to Penicillin G (94.4\%). More over coagulase negative staphylococci (CNS) have showed high susceptibility (100.0\%) to Gentamycin, Kanamycin and Chloramphenicol; but they were slightly resistant to Cloxacillin (63.6\%).
In respect to resistance 40/55 (72.7\%) (Table 5) staphylococcal species have developed a multi drug resistance. The result also shows 20/22 (90.4\%), 1/4 (25.0\%), 13/18 (72.2\%), and 6/11 (54.5\%) of multi drug resistance was developed in S. aureus, S. intermedius, S. hyicus and CNS, respectively. And generally only 2/55 (3.6\%) staphylococcal isolates have shown no resistance against the previously mentioned fifteen antimicrobials (Table 5).

\section{Discussion}

Staphylococcus species are prevalent food-borne bacterial pathogens that cause food poisoning in humans when ingested in contaminated foods, including dairy products. They cause SFP by toxin production [27]. Staphylococcus species can indeed be easily eliminated from foods by heat treatment (in pasteurized foods) or by competition with other flora (in fermented foods), whereas SEs resist most of the treatments used during food processing. Hence, the surveillance of food for microbial contamination is vital for the protection of public health and consumer interests. Production of safe food also has important economic implications in an increasingly competitive global market. The organisms can gain access to raw milk and milk products either by direct excretion from udders having clinical and subclinical staphylococcal mastitis or by contamination from food handlers [28,29].

\begin{tabular}{|c|c|c|c|c|c|}
\hline \multirow[b]{2}{*}{ Sample type } & \multicolumn{4}{|c|}{ Staphylococcal species ( $\mathrm{n} \%)$} & \multirow[b]{2}{*}{ Total $(\mathbf{n} \%)$} \\
\hline & S. aureus & S. intermedius & S. hyicus & CNS & \\
\hline MS (n=66) & $13(19.7)$ & $2(3)$ & $13(19.7)$ & $7(10.6)$ & $35(53.0)$ \\
\hline $\mathrm{KS}(\mathrm{n}=7)$ & $3(42.9)$ & $0(0.0)$ & $1(14.3)$ & $1(14.3)$ & $5(71.4)$ \\
\hline $\operatorname{SLS}(n=7)$ & $3(42.9)$ & $0(0.0)$ & $0(0.0)$ & $0(0.0)$ & $3(42.9)$ \\
\hline AHS $(n=7)$ & $3(42.9)$ & $0(0.0)$ & $0(0.0)$ & $0(0.0)$ & $3(42.9)$ \\
\hline ANS $(n=7)$ & $0(0.0)$ & $0(0.0)$ & $1(14.3)$ & $3(42.9)$ & $4(51.7)$ \\
\hline UM $(n=42)$ & $5(11.9)$ & $2(4.8)$ & $4(9.5)$ & $8(19.0)$ & $19(45.2)$ \\
\hline $\mathrm{TM}(\mathrm{n}=9)$ & $1(11.1)$ & $1(11.1)$ & $1(11.1)$ & $0(0.0)$ & $3(33.3)$ \\
\hline$B S(n=9)$ & $0(0.0)$ & $1(11.1)$ & $0(0.0)$ & $2(22.22)$ & $3(33.3)$ \\
\hline TS $(n=9)$ & $3(33.3)$ & $0(0.0)$ & $0(0.0)$ & $0(0.0)$ & $3(33.3)$ \\
\hline $\mathrm{FHS}(n=9)$ & $1(11.1)$ & $0(0.0)$ & $2(22.2)$ & $0(0.0)$ & $3(33.3)$ \\
\hline FNS $(n=9)$ & $3(33.3)$ & $0(0.0)$ & $2(22.2)$ & $3(33.3)$ & $8(88.9)$ \\
\hline Total (N\%) & $35(19.3)$ & $6(3.3)$ & $24(13.3)$ & $24(13.3)$ & $89(49.2)$ \\
\hline $\mathrm{X}^{2}$ (P Value) & $15.82(0.11)$ & $5.59(0.85)$ & $9.01(0.52)$ & $17.02(0.07)$ & $11.76(0.30)$ \\
\hline
\end{tabular}

Key: MS: Meat Swab; KS: Knive Swab; SLS: Slaughter Line Swab; AHS: Abattoir Hand Swab; ANS: Abattoir Nasal Swab; UM: Udder Milk; TM: Tank Milk; BS: Bucket Swab; TS: Tank Swab; FHS: Farm Nasal Swab; FNS: Farm Nasal Swab; CNS: Coagulase Negative Staphylococci.

Table 2: Number and percentage of Staphylococcus species with samples type taken in and around Asella municipal abattoir and selected dairy cattle farms.

\begin{tabular}{|c|c|c|c|c|}
\hline \multirow{2}{*}{ S. No } & \multirow{2}{*}{ Name of antimicrobial } & \multicolumn{3}{|c|}{ Susceptibility pattern } \\
\hline & & Susceptible (n \%) & Intermediate (n \%) & Resistant (n \%) \\
\hline 1 & Amoxicillin (AML) & $32(58.2)$ & $0(0.0)$ & $23(41.8)$ \\
\hline 2 & Cefoxitin (FOX) & $37(67.3)$ & $0(0.0)$ & $18(32.7)$ \\
\hline 3 & Chloramphenicol (C) & $45(81.8)$ & $0(0.0)$ & $10(18.2)$ \\
\hline 4 & Ciprofloxacin (CIP) & $45(81.8)$ & $7(12.7)$ & $3(5.5)$ \\
\hline 5 & Cloxacillin (OB) & $26(47.3)$ & $0(0.0)$ & $29(52.7)$ \\
\hline 6 & Erythromycin (E) & $34(61.8)$ & $10(18.2)$ & $11(20.0)$ \\
\hline 7 & Gentamicin (CN) & $52(94.5)$ & $2(3.6)$ & $1(1.8)$ \\
\hline 8 & Kanamycin (K) & $49(89.1)$ & $2(3.6)$ & $4(7.3)$ \\
\hline 9 & Nalidixic acid (NA) & $14(25.5)$ & $9(16.4)$ & $32(58.2)$ \\
\hline 10 & Nitrofurantion (F) & $25(45.5)$ & $7(12.7)$ & $23(41.8)$ \\
\hline 11 & Penicillin G (P) & $8(14.5)$ & $0(0.0)$ & $47(85.5)$ \\
\hline 12 & Streptomycin (S) & $36(65.5)$ & $10(18.2)$ & $9(16.4)$ \\
\hline 13 & $\begin{array}{c}\text { Sulphamethoxazole trimethoprim } \\
\text { (SXT) }\end{array}$ & $45(81.8)$ & $4(7.3)$ & $6(10.9)$ \\
\hline 14 & Tetracycline (TE) & $34(61.8)$ & $8(14.5)$ & $13(23.6)$ \\
\hline 15 & Vancomycin (VA) & $38(69.1)$ & $0(0.0)$ & $17(30.9)$ \\
\hline
\end{tabular}

Table 3: Antimicrobial susceptibility of staphylococcal isolates $(n=55)$. 
Citation: Abunna F, Abriham T, Gizaw F, Beyene T, Feyisa A, et al. (2016) Staphylococcus: Isolation, Identification and Antimicrobial Resistance in Dairy Cattle Farms, Municipal Abattoir and Personnel in and Around Asella, Ethiopia. J Vet Sci Technol 7: 383. doi: 10.4172/21577579.1000383

Page 5 of 7

\begin{tabular}{|c|c|c|c|c|c|c|c|c|c|c|c|c|}
\hline \multirow{3}{*}{$\begin{array}{l}\text { Drug } \\
\text { name }\end{array}$} & \multicolumn{12}{|c|}{ Antimicrobial susceptibility pattern of Staphylococcus species } \\
\hline & \multicolumn{3}{|c|}{ S. aureus } & \multicolumn{3}{|c|}{ S. intermedius } & \multicolumn{3}{|c|}{ S. hyicus } & \multicolumn{3}{|c|}{ CNS } \\
\hline & $\mathrm{S} n \%$ & In $\mathrm{n} \%$ & R n\% & $\mathrm{S} n \%$ & $\mathrm{In} \%$ & R n\% & $\mathbf{S} \mathbf{n} \%$ & $\ln \%$ & $\mathrm{R} n \%$ & S n\% & $\ln \%$ & $\mathrm{Rn} \%$ \\
\hline AML & $13(59.1)$ & $0(0.0)$ & $9(40.9)$ & $4(100)$ & $0(0.0)$ & $0(0.0)$ & $7(38.9)$ & $0(0.0)$ & 11(61.1) & $8(72.7)$ & $0(0.0)$ & $3(27.3)$ \\
\hline FOX & 19(86.4) & $0(0.0)$ & $3(13.6)$ & $2(50.0)$ & $0(0.0)$ & $2(50.0)$ & $8(44.4)$ & $0(0.0)$ & 10(55.6) & $8(72.7)$ & $0(0.0)$ & $3(27.3)$ \\
\hline C & $15(68.2)$ & $0(0.0)$ & $7(31.8)$ & $4(100)$ & $0(0.0)$ & $0(0.0)$ & $15(83.3)$ & $0(0.0)$ & $3(16.7)$ & $11(100)$ & $0(0.0)$ & $0(0.0)$ \\
\hline $\mathrm{CIP}$ & 18(81.8) & $3(13.6)$ & 1(4.5) & $3(75.0)$ & $1(25.0)$ & $0(0.0)$ & 14(77.8) & $2(11.1)$ & 2(11.1) & 10(90.9) & 1(9.1) & $0(0.0)$ \\
\hline OB & $13(59.1)$ & $0(0.0)$ & $9(40.9)$ & $3(75.0)$ & $0(0.0)$ & $1(25.0)$ & $6(33.3)$ & $0(0.0)$ & $12(66.7)$ & $4(36.4)$ & $0(0.0)$ & $7(63.6)$ \\
\hline E & 14(63.6) & $4(18.2)$ & $49(18.2)$ & $3(75.0)$ & $1(25.0)$ & $0(0.0)$ & $9(50.0)$ & $5(27.8)$ & $4(22.2)$ & $8(72.7)$ & $0(0.0)$ & $3(27.3)$ \\
\hline $\mathrm{CN}$ & $20(90.9)$ & $2(9.1)$ & $0(0.0)$ & $4(100)$ & $0(0.0)$ & $0(0.0)$ & 17(94.4) & $0(0.0)$ & $1(5.6)$ & $11(100)$ & $0(0.0)$ & $0(0.0)$ \\
\hline $\mathrm{K}$ & 20(90.9) & $1(4.5)$ & $1(4.5)$ & $4(100)$ & $0(0.0)$ & $0(0.0)$ & 14(77.8) & $1(5.6)$ & $3(16.7)$ & $11(100)$ & $0(0.0)$ & $0(0.0)$ \\
\hline NA & $3(13.6)$ & $5(22.7)$ & 14(63.6) & $1(25.0)$ & $1(25.0)$ & $2(50.0)$ & $6(33.3)$ & $2(11.1)$ & $10(55.6)$ & $4(36.4)$ & $1(9.1)$ & $6(54.5)$ \\
\hline $\mathrm{F}$ & $9(40.9)$ & $5(22.7)$ & $8(36.4)$ & $2(50.0)$ & $0(0.0)$ & $2(50.0)$ & $6(33.3)$ & $2(11.1)$ & $10(55.6)$ & $8(72.7)$ & $0(0.0)$ & $3(27.3)$ \\
\hline$P$ & $1(4.5)$ & $0(0.0)$ & $21(95.5)$ & $1(25.0)$ & $0(0.0)$ & $3(75.0)$ & $1(5.6)$ & $0(0.0)$ & $17(94.4)$ & $5(45.5)$ & $0(0.0)$ & $6(54.5)$ \\
\hline S & $15(68.2)$ & $3(13.6)$ & $4(18.2)$ & $3(75)$ & $1(25.0)$ & $0(0.0)$ & $11(61.1)$ & $3(16.7)$ & $4(22.2)$ & $7(63.6)$ & $3(27.3)$ & 1(9.1) \\
\hline SXT & 19(86.4) & $0(0.0)$ & $3(13.6)$ & $4(100)$ & $0(0.0)$ & $0(0.0)$ & $12(66.7)$ & $4(22.2)$ & $2(11.1)$ & 10(90.9) & $0(0.0)$ & $1(9.1)$ \\
\hline TE & $13(59.1)$ & $2(9.1)$ & $7(31.8)$ & $4(100)$ & $0(0.0)$ & $0(0.0)$ & $9(50.0)$ & $4(22.2)$ & $5(27.8)$ & $8(72.7)$ & $2(18.2)$ & $1(9.1)$ \\
\hline VA & $18(81.8)$ & $0(0.0)$ & $4(18.2)$ & $4(100)$ & $0(0.0)$ & $0(0.0)$ & $8(44.4)$ & $0(0.0)$ & $10(55.6)$ & $8(72.7)$ & $0(0.0)$ & $3(27.3)$ \\
\hline
\end{tabular}

Key: S: Susceptible; I: Intermediate; R: Resistant; n: Number; CNS: Coagulase Negative Staphylococcus AML: Amoxicillin (25 $\mu$ g); FOX: Cefoxitin (30 $\mu$ g); C:

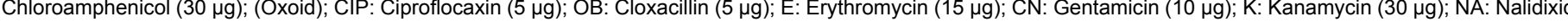
acid $(30 \mu \mathrm{g})$; F: Nitrofurantion $(50 \mu \mathrm{g})$; P: Penicillin G (10 units); S: Streptomycin $(10 \mu \mathrm{g})$; SXT: Sulphamethoxazole trimethoprim $(25 \mu \mathrm{g})$; TE: Tetracycline $(30 \mu \mathrm{g})$; VA: Vancomycin $(30 \mu \mathrm{g})$

Table 4: Antimicrobial susceptibility patterns of each Staphylococcus species.

\begin{tabular}{|c|c|}
\hline Number of antimicrobials & Resistance (number and percentage) \\
\hline Zero & $2(3.6)$ \\
\hline One & $4(7.3)$ \\
\hline Two & $9(16.4)$ \\
\hline Three & $6(10.9)$ \\
\hline Four & $9(16.4)$ \\
\hline Five & $8(14.5)$ \\
\hline Six & $5(9.1)$ \\
\hline Seven & $2(3.6)$ \\
\hline Eight & $5(9.1)$ \\
\hline Nine & $1(1.8)$ \\
\hline Ten & $1(1.8)$ \\
\hline Eleven & $2(3.6)$ \\
\hline Thirteen & $1(1.8)$ \\
\hline Total & $\mathbf{5 5 ( 1 0 0 . 0 )}$ \\
\hline MDR & $40(72.7)$ \\
\hline
\end{tabular}

MDR: Multi Drug Resistant

Table 5: Number and percentages of resistant staphylococcal isolates to antimicrobials.

In fact, tissues from healthy animal are sterile however, it has been pointed that during slaughter, dressing and cutting, microorganisms are introduced chiefly from the exterior of the animal and its intestinal tract but in general more microorganisms are added from knives, cloths, air, carts and equipment's. External contamination of meat will occur possibility from the moment of bleeding until consumption [21]. Among the factors that affect microbial growth in meat are intrinsic properties (physical and chemical properties of meat) and extrinsic (environmental factors), however the factors having the greatest influence on the growth of microorganisms in meat and meat products are the storage temperature, moisture and oxygen availability [30]. The possible sources of these bacteria are likely resulted from the skin of the animal from which the meat was obtained. Other potential sources of microbial contaminations are the equipment used for each operation until the final product is eaten; the clothing and hands of personnel and the physical facilities themselves are all implicated [22].

In the present study, 181 samples consisting of 94 municipal abattoirs, 87 dairy cattle farm originated samples were examined.

The isolation and identification results proved the presence of the Staphylococcus in abattoir and farm originated samples examined in the study area. As the result, the proportion of Staphylococcus was found to be $53.2 \%$ (50/94), and $44.8 \%$ (39/87) from abattoir, and farm samples respectively. The overall proportion of Staphylococcus was $49.2 \%(89 / 181)$. A high proportion of Staphylococcus was recorded in municipal abattoir than dairy cattle farm samples. The reason for these could be hypothesized to be the poor hygienic status of the municipal abattoir. The proportional distribution of Staphylococcus among sample types is $35 / 66(53.0 \%)$ in meat swab, $5 / 7(71.4 \%)$ in polled knives swab, 3/7 (42.9\%) in slaughter line swab, 3/7 (42.9\%) in polled abattoir hand swab, 4/7 (57.1\%) in polled abattoir nasal swab, 19/42 (45.2\%) in udder milk, 3/9 (33.3\%) in tank milk, 3/9 (33.3\%)in polled bucket swab, 3/9 (33.3) tank swab, 3/9 (33.3\%) polled farm hand swab and 8/9 (88.9\%) polled farm nasal swab. From the samples containing staphylococci, $S$. aureus was detected $19.3 \%$ (35/181) of which $23.4 \%$ (22/50) abattoir and $14.9 \%(13 / 39)$ from farm samples. The farm result was slightly lower than $15.5 \%$ (51/328), [31] in around Addis Ababa; $17.2 \%$, [32] in Egypt and 19.5\%, [33] who isolated S. aureus strains from human and animal sources. Of the farm sample 5/42 (11.9\%), 1/9 (11.1\%), $0(0.0 \%)$, $3 / 9(33.3 \%), 1 / 9(11.1 \%)$, and 3/9 (33.3\%); udder milk, tank milk, polled bucket swab, tank swab, polled hand and nasal swab, respectively, were positive for $S$. aureus The findings of the present study revealed a lower proportional rate than $75 \%$ in 220 bovine bulk milk reported in [34], $68 \%(15 / 22)$ in [5], $61.3 \%(49 / 80)$ in [35], and $40 \%(32 / 81)$ in [36], but higher than [37] which was $8 \%(8 / 100)$ in udder milk and $10 \%(10 / 100)$ in tank milk. Also the present result shows the proportion of $S$. aureus in polled farm nasal swab 3/9 (33.3\%) was higher than [38], 4/31(13\%) and [33] who reported $20 \%$ from nasal swabs of diseased human. The difference in percentage of $S$. aureus in these reports could be explained either by the different microbiological techniques used in these studies, differences in the origin of the samples or by geographical differences. The $S$. aureus incidence at a considerable high percentage indicates the alarming situation both for dairy farms and for public health as well.

As the result shows $S$. intermedius have an overall proportion of 6/181 (3.3\%), of which 2/94 (2.1\%) and 4/87 (4.6\%) are from abattoir and farm respectively. In addition, the proportion of $S$. intermedius 
Citation: Abunna F, Abriham T, Gizaw F, Beyene T, Feyisa A, et al. (2016) Staphylococcus: Isolation, Identification and Antimicrobial Resistance in Dairy Cattle Farms, Municipal Abattoir and Personnel in and Around Asella, Ethiopia. J Vet Sci Technol 7: 383. doi: 10.4172/21577579.1000383

Page 6 of 7

was $2 / 66(3 \%), 2 / 42(4.8 \%), 1 / 9(11.1 \%), 1(11.1 \%)$ in meat swab, udder milk, tank milk and bucket swab respectively, which was lower than [37] of $6 / 100(6 \%)$ bucket milk and in agreement with $11 / 100(11 \%)$ tank milk, but higher than $2 \%$ of 81 milk and milk product samples by [36]. The difference may be due to different procedures followed, geographical differences and origin of sample.

From 181 samples $24(13.3 \%)$ was isolated to be $S$. hyicus, of these $13 / 66$ (19.7\%), 1/7 (14.3\%), 1/7 (14.3\%), 4/42 (9.5\%), 1/9 (11.1\%), 2/9 (22.2\%), and 2/9 (22.9\%); meat swab, polled knives swab, polled abattoir nasal swab, udder milk, tank milk, polled hand swab and polled farm nasal swabs respectively were distinguished. This result was higher than [37] who reported 6/100 (6\%) bucket milk and 6/100 (6\%) tank milk in Bishoftu town. This was may be due to poor hygienic status of the area.

In the past, CNS was often regarded as skin flora opportunists but recent data now indicate that they are associated with several subclinical and clinical infections [39]. In the current study $7 / 66$ (10.6\%) meat swab, 1/7 (14.3\%) polled knives swab, 3/7 (42.9\%) polled abattoir nasal swab, 8/42 (19.0\%) udder milk, 2/9 (22.2\%) polled bucket swab, 3/9 (33.3\%) polled farm nasal swab was obtained with overall proportion of $24 / 181(13.3 \%)$. It was lower than the investigation of [40] who reported CNS 54\% in raw milk of cattle in Mongolia and [41] of $29 \%$ in 1036 samples.

In the current study 55 staphylococcal isolates were tested using fifteen antimicrobials. From these isolates Gentamycin, Kanamycin, Sulphamethoxazole trimethoprim, Chloramphenicol, and Ciprofloxacin were the most effective antimicrobials showing $94.5 \%$ to $81.1 \%$ susceptibility (Table 3 ). Because these drugs were the least frequently used in the study area in Veterinary services, thus no such more resistance was developed [42]. As [43] suggestion the development of antibiotic resistance is nearly always as a result of repeated therapeutic use and/or indiscriminate usage of them. The current study has showed very high level of resistance $(85.5 \%)$ of Staphylococcus species isolates against Penicillin G. Moreover S. aureus have shown the resistance of Penicillin G was found to be 95.5\% (Table 5), which is similar to [31] $96.7 \%$ and [44] $87.2 \%$. This high level of resistance was due to isolate produced a penicillinase enzyme (a type of $\beta$-lactamase) that hydrolysed the beta-lactam ring of penicillin [45].

From 55 Staphylococcus species isolates tested 40/55 (72.9\%) have developed multi drug resistance, which means those isolates are resistant to more than three antimicrobials. Staphylococcus aureus have developed higher degree of multi drug resistance 20/22 (90.9\%) which was slightly higher than [46] report (79\%). This was due to $S$. aureus strains have developed multidrug resistance worldwide with broad diversity in prevalence rate in different regions.

\section{Conclusion}

Staphylococcus species were prevalent in municipal abattoir and selected dairy cattle farms in Asella, South-eastern Ethiopia. Staphylococcus aureus was proportionally higher when compared to another Staphylococcal species. Over all, the presence of pathogenic Staphylococcus poses a health hazard and rise concerns about the safety of these food products. In addition, antimicrobial susceptibility showed that Staphylococcus species are highly sensitive to Gentamicin, Kanamycin, Chloramphenicol, Ciprofloxacillin, and Sulphamethoxazole trimethoprim; and also are more resistant Penicillin and Nalidixic acid. Moreover, most of Staphylococcus species isolates have developed multi drug resistance.

\section{Conflict of Interests}

The authors have not declared any conflict of interests.

\section{Authors' Contributions}

TB participated in research coordination, study design, data analysis, Antimicrobial susceptibility tests, and manuscript drafting and final revision. TA participated in sample collection, bacterial culture and identification Antimicrobial susceptibility tests and drafting manuscript. FG participated in study supervision, bacterial identification and Antimicrobial susceptibility tests. RD conceived the research idea and participated in its design, coordination and data analysis. TB, $\mathrm{AF}, \mathrm{DA}, \mathrm{BM}$ coordinated and supervised the study, provided valuable information and the design of the study. All authors agreed with the results and conclusions; and read and approved the final manuscript.

\section{Acknowledgements}

The authors greatly appreciate Addis Ababa University for funding this research.

\section{References}

1. Baron F (2007) Review on Staphylococcus aureus and food poisoning. Genet Mol Res 2: 163-176.

2. Pal M (2007) Zoonoses. 2nd edn. Satyam Publishers, Jaipur, India, pp: 138-139.

3. Hobbs BC, Roberts D (1981) Food Poisoning and Food Hygiene. 4th edn Edward Arnold, London, Great Britain, p: 27.

4. Ash M (2008) Staphylococcus aureus and Staphylococcal Enterotoxins. In Foodborne microorganisms of public health importance. 5th edn. AIFST (NSW Branch), Sydney, Australia, pp: 313-332.

5. Loir Y, Baron F, Gautier M (2003) Staphylococcus aureus and food poisoning Genet Mol Res 2: 63-76.

6. Kerouanton A, Hennekinne J, Letertre C, Petit L, Chesneau O, et al. (2007) Characterization of Staphylococcus aureus strains associated with food poisoning outbreaks in France. Int J Food Microbiol 115: 369-375.

7. Aycicek H, Cakiroglu S, Stevenson T (2005) Incidence of Staphylococcus aureus in ready to eat meals from military cafeterias in Ankara, Turkey. Food Control 16: 531-534.

8. Bania J, Dabrowska A, Bystron J, Korzekwa K, Chrzanowska J, et al. (2006) Distribution of newly described enterotoxin-like genes in Staphylococcus aureus from food. Int J Food Microbiol 108: 36-41.

9. World Health Organization (2007) Food Safety - Food borne diseases and value chain management for food safety. "Forging links between Agriculture and Health" CGIAR on Agriculture and Health Meeting in WHO/HQ.

10. Essex-caster A (1987) A synopsis of public health and social medicine. 2nd edn. Sons Ltd., Bristol: Sohn Wright.

11. Hopkins RS, Juranek DD (1991) Acute giardiasis: an improved clinical case definition for epidemiologic studies. Am J Epidemiol 133: 402-407.

12. Ateba CN, Mbewe M, Moneoang MS, Bezuidenhout CC (2010) Antibioticresistant Staphylococcus aureus isolated from milk in the Mafikeng Area, North West province, South Africa. S Afr J Sci 106: 1-6.

13. Zadoks R, van Leeuwen W, Barkema H, Sampimon O, Verbrugh H, et al. (2000) Application of pulsed-field gel electrophoresis and binary typing as tools in veterinary clinical microbiology and molecular epidemiologic analysis of bovine and human Staphylococcus aureus isolates. J Clin Microbiol 38: 1931-1939.

14. Asao T, Kumeda Y, Kawai T, Shibata T, Oda H, et al. (2003) An extensive outbreak of staphylococcal food poisoning due to low-fat milk in Japan: estimation of enterotoxin $A$ in the incriminated milk and powdered skim milk. Epidemiol Infect 130: 33-40.

15. Lee JH, Jeong JM, Park YH, Choi SS, Kim YH, et al. (2004) Evaluation of the methicillin-resistant Staphylococcus aureus (MRSA)-screen latex agglutination test for detection of MRSA of animal origin. J Clin Microbiol 42: 2780-2782.

16. Jay J (2000) Modern Food Microbiology. 6th edn., Aspen Food Science Text Series, Aspen Publishers Inc., Gaithersburg, Maryland, pp: 441-456.

17. Smith K (2007) Handbook of Foodborne pathogenic microorganisms and natural toxins. Food and Drug Administration, Center for Food Safety and Appl Nutr 10: 119-150.

18. Murray P, Rosenthal KS, Pfaller MA (2015) Microbiología médica. Elsevier, Brasil.

19. Yousuf A, Ahmed M, Yeasmin S, Ahsan N, Rahman M, et al. (2008) Prevalence of Microbial Load in Shrimp, Penaeus monodon and Prawn, Macrobrachium rosenbergii from Bangladesh. World J Agric Sci 4: 852-855. 
Citation: Abunna F, Abriham T, Gizaw F, Beyene T, Feyisa A, et al. (2016) Staphylococcus: Isolation, Identification and Antimicrobial Resistance in Dairy Cattle Farms, Municipal Abattoir and Personnel in and Around Asella, Ethiopia. J Vet Sci Technol 7: 383. doi: 10.4172/21577579.1000383

20. Lawrie RA (1984) The preservation effect of smoke on meat. Meat Science Pergaman Press Inc., Maxwell House Fair View Park-Elmford, New York, pp: 49-52.

21. Rombouts F, Nouts R (1994) Food Microbiology and Hygiene. Encyclopedia Hum Biol Acad Press 3: 661-665.

22. Wagner AB Jr (2008) Bacterial Food Poisoning. Texas Agri Life Extension.

23. Walderhaug $M(2007)$ Food borne pathogenic microorganisms and natural toxins. Food and Drug Administration, Centre for Food Safety and Applied Nutrition 28: 48-65.

24. Plan A (2007) Economic Development Office (APEDO) Socio Economic on Arsi Zone.

25. CLSI (2008) Performance Standards for Antimicrobial Disk and Dilution Susceptibility Tests for Bacteria Isolated from Animals. Clinical and Laboratory Standards Institute 28: M31-A3.

26. Salandra G, Goffredo E, Pedarra C, Nardella M, Parisi A, et al. (2008) Occurrence, characterization and antimicrobial resistance pattern of Staphylococcus species isolated from dairy products in southern Italy. Int J Food Microbiol 9: 327-360.

27. Soomro A, Arain M, Khashkeli M, Bhutto B, Memon A (2003) Isolation of Staphylococcus aureus from milk products sold at sweet-meat shops of Hyderabad, Pakistan. Online J Biol Sci 3: 91-94.

28. Kalorey DR, Shanmugam Y, Kurkure NV, Chousalkar KK, Barbuddhe SB (2007) PCR-based detection of genes encoding virulence determinants in Staphylococcus aureus from bovine subclinical mastitis cases. J Vet Sci 8: 151-154.

29. Forest DC, Harold DA, Judge BA, Robert EA (1985) Different Types of Mea and Meat product consumed by Nigerian. Principle of meat science. Pub WA Freeman and Co., pp: 4-178.

30. Mekuria A, Asrat D, Woldeamanuel Y, Tefera G (2013) Identification and antimicrobial susceptibility of Staphylococcus aureus isolated from milk samples of dairy cows and nasal swabs of farm workers in selected dairy farms around Addis Ababa, Ethiopia. Afr J Microbial Res 7: 3501-3510.

31. El-Seedy FR, El-Shabrawy M, Hakim AS, Dorgham SM, Ata S, et al. (2010) Recent Techniques used for isolation and characterization of Staphylococcus aureus from mastitic cows. Am J Sci 6: 1-8.

32. Jakee J, Nagwa S, Bakry M, Sahar A, Zouelfakar E, et al. (2008) Characteristics of Staphylococcus aureus strains isolated from human and animal sources. J Agric Environ Sci 4: 221-229.

33. Jorgensen H, Mork T, Rorvik L (2005) The occurrence of Staphylococcus aureus on a farm with small-scale production of raw milk cheese. J Dairy Sci 88: $3810-3817$
34. Hein I, Jorgensen H, Loncarevic S, Wagner M (2005) Quantification of Staphylococcus aureus in unpasteurised bovine and caprine milk by real-time PCR. Res Microbiol 156: 554-563.

35. Bendahou A, Lebbadi M, Ennanei L, Essadqui F, Abid M (2008) Characterization of Staphylococcus species isolated from raw milk and milk products (Iben and jben) in North Morocco. J Infect Dev Ctries 2: 218-225.

36. Tegegne MA (2009) Isolation and identification of Staphylococcus species from cottage cheese and raw bovine milk in Debre zeit, Ethiopia. MSc Thesis, Faculty of Veterinary Medicine, Addis Ababa University, Debreziet, Ethiopia.

37. Kateete D, Kabugo U, Baluku H, Nyakarahuka L, Kyobe S, et al. (2013) Prevalence and Antimicrobial Susceptibility Patterns of Bacteria from Milkmen and Cows with Clinical Mastitis in and around Kampala, Uganda. PLoS ONE 8: e63413.

38. Shah M (2003) Molecular pathogenesis of Staphylococcus aureus and other staphylococci. J Appl Bacteriol 59: 207-221.

39. Tsegmed $U$ (2006) Staphylococci isolated from raw milk of yak and cattle in Mongolia. Studies on the occurrence, characterization, detection of enterotoxin and antimicrobial susceptibility profile of the isolates. Swedish University of Agricultural Sciences, Uppsala, Sweden.

40. Lamprell H, Villard L, Chamba JF, Beuvier E, Borges E, et al. (2004) Identification and biotyping of coagulase-positive staphylococci (CPS) in ripened French raw milk cheeses and their in vitro ability to produce enterotoxins. Rev Med Vet 155: 92-96.

41. Birhanu A, Diriba L, lyob I (2013) Study of bovine mastitis in Asella government dairy farm of Oromia Regional state, South Eastern Ethiopia. Int J Curr Res Acca Rev 1: 134-145.

42. Jaimes EC, de los Monteros LEE, Renata D (2002) Epidemiology of drug resistance; the case of Staphylococcus aureus and coagulase negative staphylococci infections. Salud pública Méx 44: 108-112.

43. Sori T, Hussien J, Bitew M (2011) Prevalence and susceptibility assay of Staphylococcus aureus isolated from bovine mastitis in dairy farms of Jimma town, South West Ethiopia. J Anim Vet Adv 10: 745-749.

44. Cavalieri SJ, Harbeck RJ, McCarter YS, Ortez JH, Rankin ID, et al. (2005) Manual of antimicrobial susceptibility testing. American Society for Microbiology. Library of Congress Cataloging-in-Publication Data, USA, p: 102.

45. Chao G, Zhou X, Jiao X (2007) Prevalence and antimicrobial resistance of food borne pathogens isolated from food products in China. Foodborne Pathog Dis 4: $277-284$

46. Normanno G, La Salandra G, Dambrosio A, Quaglia NC, Corrente M, et al. (2007) Occurrence, characterization and antimicrobial resistance of enterotoxigenic Staphylococcus aureus isolated from meat and dairy products. Int J Food Microbiol 115: 290-296. 